\title{
Leading Russia as the New Israel: Authorship and Authority in Fedor Glinka's Letters of a Russian Officer and Experiments in Sacred Verse
}

\author{
PAMELA DAVIDSON
}

He fell like a pillar. Flourish, fatherland!

My Israel, from your sons

The reproach of shame has been removed:

Know neither captivity nor fetters!

Fedor Glinka, "Victory"

Prophet! Hearken to My words

And proclaim them in the ears of the peoples:

Fedor Glinka, "The Crown of the Ages"

$\mathrm{T}_{\mathrm{h}}$

he characterization of Christians as a New Israel was a stock rhetorical device of the New Testament and early patristic writing, subsequently taken up and developed in several literary traditions. Not surprisingly, the character and purpose of these adaptations varied considerably according to the receiving culture. In a recent study of the reworking of the trope of chosenness in Anglo-Saxon verse, Samantha Zacher identified three distinct stages in its evolution: an "ecclesiastical model," rooted in Bede's view of the Church as a New Israel, a "sovereignty model," embedding the concept of sacral kingship from the age of Alfred, and an "interpretive model," developed by biblical translators, commentators, and

I would like to thank the anonymous reviewers of Russian Review for their thoughtful suggestions. This article forms part of a wider project on "Prophecy and Power in the Russian Literary Tradition (1680-1930)," generously supported by The Leverhulme Trust with the award of a two-year Research Fellowship.

The Russian Review 77 (April 2018): 2-23

Copyright 2018 University College London. The Russian Review published by Wiley Periodicals Inc. on behalf of The Russian Review. This is an open-access article under the terms of the Creative Commons Attribution License, which permits use, distribution, and reproduction in any medium, provided the original work is properly cited. 
poets. ${ }^{1}$ In the case of Russia, the ecclesiastical and sovereignty models were combined from the outset, setting the parameters for later literary incarnations.

The trope of the chosen people was introduced into Russian letters by a succession of ecclesiastical and lay writers. In Kievan Rus' the priest and future metropolitan Ilarion used it in his sermons to frame his vision of Vladimir's providential mission. The idea of Muscovy as the New Israel became widespread in sixteenth- and seventeenth-century Russia. As Daniel Rowland has shown, it was extensively developed in official state and religious discourse, iconography, and architecture, overtaking the idea of Moscow as the Third Rome. Patriarch Nikon's New Jerusalem monastery on the Istra River, with its reconstruction of Jerusalem's Church of the Holy Sepulchre, offers a striking example. ${ }^{2}$ By contrast, the Archpriest Avvakum, who led the opposition to the patriarch's reforms, condemned the Nikonians as idolatrous worshippers of Baal and represented the Old Believers as the "true" New Israel. ${ }^{3}$

Maureen Perrie correctly observed that by 1700 , together with the idea of the Third Rome, "the idea of Russia as the New Israel was also in retreat ... having been censured by opponents of the sacralization of the monarch, and discredited by the criticisms of Nikon's New Jerusalem monastery." However, her concluding comment that "although the concept of the Third Rome was rediscovered by the Russian intelligentsia in the 19th century ... the idea of the New Israel underwent no such revival in educated Russian society" is challenged by the evidence presented in this article, particularly, as we shall see, by the active cult of Russia as the New Israel developed by Fedor Glinka and his contemporaries. ${ }^{4}$

In the late seventeenth and early eighteenth centuries the hieromonks Simeon Polotsky and Feofan Prokopovich created new rhymed versions of the Psalms and incorporated the notion of Russia as a New Israel into their eulogies of the reigning monarch. ${ }^{5}$ In the latter part of the eighteenth and early nineteenth century several writers, including Trediakovsky, Lomonosov, Sumarokov, and Derzhavin, continued to assimilate the Psalms and Hebrew

${ }^{1}$ Samantha Zacher, Re-writing the Old Testament in Anglo-Saxon Verse: Becoming the Chosen People (London, 2013), 25.

${ }^{2}$ Daniel B. Rowland, "Moscow - the Third Rome or the New Israel?" Russian Review 55 (October 1996): 591-614.

${ }^{3}$ For an example of Avvakum's adoption of this trope see N. S. Demkova and I. V. Seseikina, "Stareishii (pechorskii) spisok 'Knigi tolkovanii i nravouchenii' Avvakuma, naidennyi V. I. Malyshevym," in Drevlekhranilishche Pushkinskogo doma: Materialy i issledovaniia, ed. V. P. Budaragin et al. (Leningrad, 1990), 96.

${ }^{4}$ Maureen Perrie, "Moscow in 1666: New Jerusalem, Third Rome, Third Apostasy," Quaestio Rossica, no. 3 (2014): 84.

${ }^{5}$ For a discussion of Simeon Polotsky's Psaltir' tsaria i proroka Davida, khudozhestvom rifmotvornym ravnomerno slogi, i soglasnokonechno, po razlichnym stikhov rodom prelozhennaia (Moscow, 1680) and the image of Russia as a New Israel in his Rifmologion ili Stikhoslov (manuscript of 1678), see Pamela Davidson, "Simeon Polotskii and the Origins of the Russian Tradition of the Writer as Prophet," Modern Language Review 112:4 (October 2017): 917-52. Feofan Prokopovich composed versions of several Psalms. See, for example, his "Metaphrasis Ps. 72," in Psaltir'v russkoi poezii XVII-XX vv., ed. B. P. Romanov (Moscow, 1995), 66-72. For his funeral oration of 1725, eulogizing Peter the Great as Russia's Moses, Solomon, and David, see Feofan Prokopovich, "Slovo na pogrebenie vsepresvetleishago derzhavneishago Petra Velikago," in Petr I v russkoi literature XVIII veka: Teksty i kommentarii, ed. S. I Nikolaev (St. Petersburg, 2006), 62-65. 
Prophets into literary tradition, composing original verse adaptations and integrating numerous biblical motifs into their odes of praise. ${ }^{6}$

In all these works, however, the comparison of Russia to a New Israel was usually restricted to the depiction of its leaders; the ordinary Russian people (narod), although implied as an imaginary construct, did not actually figure in the text. To gain wider currency, the theological and imperial constructions of Russia as the New Israel needed to be backed up by a view of the suitability of the narod to carry out its holy mission. For such a view to carry conviction, it needed to be articulated from a more personal perspective. How and when was this shift of emphasis achieved, and what were its consequences?

This article argues that a significant change was first brought about by Fedor Glinka (1786-1880) during and after the Napoleonic wars. Alexander I's mystic view of Russia's universal mission went hand in hand with his support of the Russian Bible Society, sponsorship of new translations of scripture, and proclivity for reading the Psalms, the Book of Daniel, and the Book of Revelation as prophecies of contemporary events. Encouraged by the German Pietist Johann Heinrich Jung-Stilling (1740-1817) and Baroness Juliane von Krüdener (1764-1824), he came to believe in his leading role as the savior of Europe from Napoleon the Antichrist through the formation of the Holy Alliance in 1815. ${ }^{7}$ As Mikhail Weisskopf has shown, the messianic image of Russia as a New Israel was taken up with renewed vigor in this conducive climate, fuelled by Protestant-inspired philoSemitism. ${ }^{8}$ Although Weisskopf makes a few passing references to Glinka, he does not investigate in any detail the substantial contribution made by this writer to the reshaping of this image. ${ }^{9}$ Yet, as I will demonstrate, Glinka deployed a range of innovative strategies which led to its radical transformation. In his early autobiographical Letters of a Russian Officer (Pis'ma russkogo ofitsera, 1808 and 1815-16), he developed a new form of prose, combining documentary record with moral invective addressed to the contemporary reader. For the first time, the image of Russia as a New Israel was applied to the actual narod,

${ }^{6}$ In 1743, Lomonosov, Trediakovsky, and Sumarokov held a celebrated competition to render Psalm 143 (144) into Russian; their versions were published anonymously in Tri ody parafrasticheskie (1744), reprinted as Appendix I in Vasilij Kirillovič Trediakovskij, Psalter 1753, ed. Aleksander Levitsky (Paderborn, 1989), 425-46. Trediakovsky's paraphrases of ten psalms appeared in Sochineniia i perevody kak stikhami tak $i$ prozoiu Vasil'ia Trediakovskago, vol. 2 (St. Petersburg, 1752), 63-102. In 1753, when Trediakovsky completed his translation of the Psalter, he appended "Pesni raznykh prorokov i prorochits" to his translations of the Psalms, thereby highlighting the relation of the Psalms to prophetic tradition. See Trediakovskij, Psalter 1753, 379-420. For Lomonosov's versions of seven psalms and his ode based on Job see Sobranie raznykh sochinenii v stikhakh $\mathrm{v}$ v proze Mikhaila Lomonosova. Kniga pervaia ([St. Petersburg], 1751), 3-46. Sumarokov was the only poet to publish in his lifetime a translation of the complete Psalter, included in his collected works of 1774 and 1781 under the generic title of "ody dukhovnye." Of Derzhavin's twenty-seven influential versions of the Psalms, twenty-two appeared in Sochineniia Derzhavina (St. Petersburg, 1845), 7-17.

${ }^{7}$ For valuable accounts of the background to this period see "Zvezda vostoka," in Andrei Zorin, Kormia dvuglavogo orla .... Literatura i gosudarstvennaia ideologiia v Rossii v poslednei treti XVIII-pervoi treti XIX veka (Moscow, 2001), 297-335; and Stephen Batalden, Russian Bible Wars: Modern Scriptural Translation and Cultural Authority (Cambridge, England, 2013), 12-40. On the influence of Jung-Stilling and Krüdener on Alexander I see Michael A. Pesenson, "Napoleon Bonaparte and Apocalyptic Discourse in Early NineteenthCentury Russia," Russian Review 65 (July 2006): 377-81; and Mark Jarrett, The Congress of Vienna and its Legacy: War and Great Power Diplomacy after Napoleon (London, 2014), 127-28.

${ }^{8}$ See Mikhail Weisskopf, The Veil of Moses: Jewish Themes in Russian Literature of the Romantic Era, trans. Lydia Wechsler, ed. Judith Robey (Leiden, 2012), 1-25, 99-109.

${ }^{9}$ Ibid., 10, 20, 90, 100, 123, 126, for the references to Glinka. 
made "real" through the author's detailed observations and accompanying commentary. After implanting the image in recent historical memory, Glinka went on to invest it with the authority of scripture in Experiments in Sacred Verse (Opyty Sviashchennoi Poezii, 1826). By introducing a personal, emotional tone into his poetic versions of the Psalms and Prophets, he continued to transform the image of the chosen people from a conventional rhetorical trope into a powerful individual message, aimed at reforming and elevating his readership. In the process, he carved out a role for himself as the moral teacher or new "Moses" of his nation. For this reason, he can rightly be regarded as a pivotal figure in the modern Russian literary cult of the writer as a figure of prophetic authority.

Since Glinka's contribution to this tradition was not an isolated phenomenon, we should first seek to understand how he fitted into the cultural landscape of his day. In the years leading up to 1825 he played an active role in literary life and polemics, loosely aligning himself with a group of writers who subsequently became known as the archaists. In his influential essay "The Archaists and Pushkin" (“Arkhaisty i Pushkin," 1926), Iurii Tynianov argued that this period was primarily shaped by the struggle between the Karamzinites and the archaists, rather than between romanticism and classicism, as was generally believed. He defined the archaists as the true innovators in matters of genre and poetic language, and divided them into two groups. The older archaists, led by Admiral A. S. Shishkov (1754-1851), included the poets G. R. Derzhavin (1743-1816) and Prince S. A. Shirinsky-Shikhmatov (1783-1837). An important forum for their ideas was provided by the Colloquy of Lovers of the Russian Word (Beseda liubitelei russkogo slova, 1811-16), founded by Shishkov and Derzhavin. The younger generation comprised P. A. Katenin (1792-1853), A. S. Griboedov (1795-1829) and V. K. Kiukhel'beker (1797-1846). ${ }^{10}$

Significantly, in "The Archaists and Pushkin" Tynianov did not mention Glinka as a member of either group, or discuss his work in any detail. However, in an earlier draft plan for a more extended version of this essay, he included the poet's name at the end of his list of younger "Shishkhovites." Clearly, he had some reservations about the extent to which Glinka formed part of this movement. Perhaps this was because Glinka tended to plough his own furrow, defying easy classification. His contemporaries portrayed him as an unusual, independent figure, who stuck to his chosen path with single-minded dedication and consistency. In a review from 1830, Pushkin praised him as "of all our poets, perhaps the most original." 12 Two years later Kiukhel'beker noted in his prison diary that Glinka was monotonous, obscure, and often odd, but confessed that he loved him "for the fact that he goes his own way."13

${ }^{10}$ Iu. N. Tynianov, “Arkhaisty i Pushkin,” in his Pushkin i ego sovremenniki, ed. V. V. Vinogradov, comp. V. A. Kaverin and Z. A. Nikitina (Moscow, 1968), 23-24. In proposing this new scheme, Tynianov was taking his lead from Kiukhel'beker, who had suggested a similar classification in a draft fragment from his literary calendar for 1825, albeit using the term "Slavs" (slaviane) rather than "archaists": "The Germano-Russians and the Franco-Russians are stopping their internal squabbles, so that they can join forces against the Slavs, who also have their own classicists and romantics, Shishkov and Shikhmatov can be counted among the first, Katenin, G[riboedov], Shakhovskoi, and Kiukhel'beker among the second" (ibid., 24).

${ }^{11}$ Ibid., 383.

${ }^{12}$ A. S. Pushkin, Sobranie sochinenii, ed. D. D. Blagoi et al., 10 vols. (Moscow, 1974-78), 6:47-48.

${ }^{13}$ Diary entry of March 16, 1832, in V. K. Kiukhel'beker, Puteshestvie. Dnevnik. Stat'i, ed. N. V. Koroleva and V. D. Rak (Leningrad, 1979), 108. 
Notwithstanding these reservations, there are ample grounds for linking Glinka to the archaists' agenda. He shared the anti-Western Slavophile orientation set by Shishkov, and pursued the same interrelated goals: reviving the genre of the ode, returning the literary language to its Russian roots, and creating poetic versions of biblical texts. ${ }^{14}$ His adaptations of the Psalms, Prophets, and the Book of Job developed examples already set by Derzhavin and Shirinsky-Shikhmatov, and anticipated the later experiments of Griboedov, Katenin, and Kiukhel'beker.

In keeping with Tynianov's lead, the scholar Mark Altshuller also classified Glinka as a "younger" archaist. ${ }^{15}$ It is important, however, to note that Glinka did not share the radical and, in some cases, revolutionary politics of the younger generation-like the older archaists, his political views were reactionary and monarchist. ${ }^{16}$ This difference was in part due to his more advanced age (he was some ten years older than the younger archaists); his personal participation in the campaign against Napoleon resulted in a more conservative form of patriotism, as we shall see below. We may therefore conclude that Glinka combined different features of both generations of archaists, while retaining a significant degree of independence, reflected in his transformative role.

\section{REDEFINING THE NAROD IN LETTERS OF A RUSSIAN OFFICER AND LETTERS TO A FRIEND}

Although Glinka's treatment of biblical themes has often been presented in a political light as the expression of Decembrist sympathies, such a reading is too narrow and misses the point. ${ }^{17}$ The civic and political dimensions of his writings were secondary offshoots, rooted in a profoundly religious temperament and mystical response to the reading of Holy Scripture. The sources of this brand of religious patriotism can be traced back to his early, formative years. Glinka belonged to a well-established noble family and was initially destined for a career in the army. As a student of the Petersburg Cadet corps school he came under the influence of a charismatic teacher of religion, Father Mikhail (1761-1821), later appointed

\footnotetext{
${ }^{14}$ For Tynianov, the key issue of the mid-1820s was restoring the ode, a task closely related to defining the function of the poetic word. See Iu. N. Tynianov, "Oda kak oratorskii zhanr" (1922), in his Poetika. Istoriia literatury. Kino (Moscow, 1977), 252. His draft plan for a longer essay on the archaists shows that he intended to include a separate section on the Bible and church books as "sources of archaism" (Pushkin i ego sovremenniki, 383).

${ }^{15}$ Mark Altshuller, "The Transition to the Modern Age: Sentimentalism and Pre-romanticism, 1790-1820," in The Cambridge History of Russian Literature, ed. Charles A. Moser, rev. ed. (Cambridge, England, 1992), 131. Altshuller does not discuss Glinka's work in any detail, neither in the above essay, nor in his book, Beseda liubitelei russkogo slova: U istokov russkogo slavianofil'stva, 2nd rev. ed. (Moscow, 2007).

${ }^{16} \mathrm{On}$ the many varieties of social and religious conservatism in this period, including the contributions of Shishkov and Sergei Glinka (Fedor Glinka's older brother), see Alexander M. Martin, Romantics, Reformers, Reactionaries: Russian Conservative Thought and Politics in the Reign of Alexander I (DeKalb, 1997).

${ }^{17}$ This tendency dominated late nineteenth-century and Soviet criticism, and is still widespread today. See, for example, the "civic" explanation of religious motifs in Glinka's verse in the standard Soviet editions prepared by V. G. Bazanov in 1949, 1951, and 1961, or the more recent characterization of Opyty Sviashchennoi Poezii as "the most systematic attempt at promoting a spiritually charged form of civic opposition" by a "Decembrist poet." See Harsha Ram, The Imperial Sublime: A Russian Poetics of Empire (Madison, 2003), 144.
} 
Metropolitan of St. Petersburg. ${ }^{18}$ The combination of inspiring instruction in the Russian Orthodox faith with a privileged military background and direct involvement in warfare shaped his life-long beliefs. He fought at the Battle of Austerlitz and distinguished himself for bravery in the first campaigns against Napoleon of 1805-6. Despite retiring from the army on grounds of ill-health, he returned to take part in the second round of 1812-14, arriving in Paris in June 1814 to celebrate with the victorious Russian troops. ${ }^{19}$

Glinka rose to unexpected literary fame through his account of these experiences in Letters of a Russian Officer. This work established his reputation as the earliest chronicler of the Napoleonic wars. The first edition of 1808, covering the campaigns of 1805-6, subsequently became part one of the much expanded second edition of eight parts, published in $1815-16 .^{20}$ The epistolary form in which he chose to present his diary and its initial publication in instalments allowed him to engage with his contemporary audience in a direct and immediate fashion. His book was extremely influential in shaping the new postwar sense of national identity that emerged out of Russia's changed relationship with Europe. ${ }^{21}$ The Moscow publication in 1821 of a French translation prepared by the author's older brother, Sergei Glinka, demonstrates their joint determination to reach a wider European readership.

Significantly, Glinka first defined his approach to Russia as a New Israel in the interlude between the two rounds of Napoleonic wars. The first volume of the second edition of Letters of a Russian Officer (1815) included two "peaceful" parts, recording the author's travels around provincial Russia in 1810-11 as a member of the Society of Russian History and Antiquities. Glinka explained at the outset that in the deceptive period of quiet between 1807 and 1812 he continued to keep a diary devoted to his observations of "the customs of our people" (nravy nashego naroda), paying particular attention to examples of virtue (dobrodetel') and $\sin$ (porok). ${ }^{22}$ Quoting Montesquieu's claim that a nation which has preserved its customs is not yet defeated, he noted with satisfaction that it would therefore

\footnotetext{
${ }^{18}$ Father Mikhail's secular name was Matfei Mikhailovich Desnitsky. In his autobiography of 1858, Glinka mentions Father Mikhail's considerable success in instilling religious feeling in his pupils. See F. N. Glinka, "Avtobiografiia," in Pisateli-dekabristy v vospominaniiakh sovremennikov, ed. R. V. Iezuitova et al., 2 vols. (Moscow, 1980), 1:315.

${ }^{19}$ For concise overviews of Glinka's life and works see A. A. Il'in-Tomich in Russkie pisateli, 1800-1917: Biograficheskii slovar', ed. P. A. Nikolaev, 5 vols. (Moscow, 1989-2007), 1:578-81; and Vladimir Karpets, "I mne ravny i mig, i vek ...," in Fedor Glinka, Sochineniia, comp. and ed. V. I. Karpets (Moscow, 1986), 309-28. For a more comprehensive study see V. P. Zverev, Fedor Glinka - russkii dukhovnyi pisatel' (Moscow, 2002).

${ }^{20}$ The contents of the second edition are reflected in its full title: Pis'ma ruskogo ofitsera o Pol'she, avstriiskikh vladeniiakh, Prussii i Frantsii, s podrobnym opisaniem pokhoda Rossiian protivu Frantsuzov, v 1805 i 1806, takzhe Otechestvennoi $i$ zagranichnoi voiny s 1812 po 1815 god. S prisovokupleniem zamechanii, myslei $i$ rassuzhdenii vo vremia poezdki v nekotorye otechestvennye Gubernii, 2 vols. (Moscow, 1815-16).

${ }^{21}$ See E. R. Ponomarev, "K voprosu o russkikh evropeitsakh: 'Pis'ma russkogo ofitsera' Fedora Glinki i national'noe samosoznanie," Vestnik Sankt-Peterburgskogo gosudarstvennogo universiteta kul'tury i iskusstv, 2012, no. 4:21-31; and idem, “'Pis'ma russkogo ofitsera' Fedora Glinki kak 'Puteshestvie na Zapad,"” Voprosy literatury, 2011, no. 6:160-90. On Glinka's position in the tradition of Russian travel writing see Sara Dickinson, Breaking Ground: Travel and National Culture in Russia from Peter I to the Era of Pushkin (Amsterdam, 2006), 144-55, 199-205.

${ }^{22}$ Parts 2 and 3 constitute the "peaceful parts" of the second edition. The passage cited comes from the opening of Part 2 of Pis'ma russkogo ofitsera (1815), reprinted in F. N. Glinka, Pis'ma k drugu, ed. V. P. Zverev (Moscow, 1990), 27.
} 
be very difficult to subjugate Russia. ${ }^{23}$ The connection between the "military" and the "peaceful" parts of the work was thus established on the basis of the nation's moral identity, documented by Glinka through personal observation. As an author, he was boldly taking upon himself the authority to evaluate the imperial ambitions of the state in terms of the ethical standing of its people.

With this principle in mind, Glinka then moved on to specific examples. In two early entries, "Gypsies" ("Tsygane") and "The Church" ("Tserkov"), he delivered a revealing sequence of thoughts on the role of the biblical prophets in shaping and preserving national identity. In the first entry, prompted by an encounter with some gypsies, he contrasted this itinerant people with the Jews. Both peoples live in dispersion, but whereas the Jews make up a people (narod), the gypsies do not. Glinka attributed the formation and survival of the Jewish people entirely to the prophet Moses:

If the Jews had not had Moses, then, no doubt, at the first exodus from Egypt they would have disappeared among the multitude of other peoples who had settled in that part of the land. But their wise, divinely inspired law-giver could strengthen them so firmly with habits, customs, rituals, and laws that for a few thousand years and even now, in persecution and dispersion, they still exist in the form of a people. ${ }^{24}$

He then posed the following question - if Europe were to be struck with a sudden calamity, which of its peoples would be most likely to preserve its national or moral identity? Although he rounded off this section by inviting the reader to guess the answer, he made it clear in a footnote that it would be the Russian people:

The one that is firm and unshakeable in its customs and in the faith of its forefathers. Firmness in its customs and in its native faith preserved the Russians during the three centuries of Tatar rule over Russia. ${ }^{25}$

The note ended with a dire warning, anticipating his later apocalyptic predictions. If Russia were to change its customs, it would lose all traces of its glory and disappear off the face of the earth.

The message is clear: the survival of Russia, modeled on that of the Jewish people, depends on its loyalty to its traditional faith and customs. For this purpose, it will require its own dedicated leader. Glinka has effectively prepared the ground for what was later to become an explicit theme in his verse- the view of the Russians as the new Israelites, and, in this context, his self-appointed role as Moses' successor.

A few pages later, in "The Church," Glinka moved from these initial thoughts about prophecy and nationhood to some more specific reflections on the biblical prophets. These are ingeniously introduced through an extended commentary on a series of haut-reliefs from a church in the Smolensk region, depicting various prophets and patriarchs. ${ }^{26}$ The

\footnotetext{
${ }^{23}$ Ibid., 28.

${ }^{24}$ Ibid., 36.

${ }^{25}$ Ibid.

${ }^{26}$ Glinka refers to a church in "Selo $\mathrm{P}$ " on the bank of the Dnieper. The location is not specified by Zverev, the editor of Pis'ma k drugu. Riazantsev and Evangulova subsequently identified the village as Nikolo-Pogoreloe
} 
five haut-reliefs singled out by Glinka for a detailed account illustrate different aspects of prophecy. They show John the Baptist, the forerunner of the Christian Messiah; Moses, giving the ten commandments to the people; the miraculous salvation of baby Moses; suffering Job, taking solace in divine providence; and Abraham, offering hospitality to the three angels. Glinka described each scene in turn, but only provided a voice for Moses. After recounting the prophet's descent from Sinai with the tablets, he imagined his speech to the nation:

The entire people with reverential delight falls on its knees, and Moses with a triumphant face, with a kind of holy smile, it seems, speaks to the people and the whole world: "Look, how simple, short and instructive God's prophecies are! ... Compared to them, what are all the lengthy, contrived fabrications of mortals? ... May these ten divine commandments - he continues - may they be dearer to you than your wives and children." ${ }^{.7}$

Those who keep the commandments are promised rewards, including peace at home and the ability to inspire fear in their "adversaries" (supostatam) (a term often denoting Napoleon). ${ }^{28}$ This early example of Glinka assuming the prophetic voice of Moses uses the ecphrastic description of the haut-reliefs as a springboard to convey his own teaching to the Russian people.

In a later entry Glinka identified the creator of the "carved pictures" as Boris Poliakov, a pupil of the Academy, and concluded with a telling exclamation: "Glory to the Russian artist!"29 Poliakov was praised because his work revealed the true calling of a Russian artist: to convey the teachings of the biblical prophets to the Russian nation. Through his commentary Glinka translated the original visual images into the language of words, thereby forging a prophetic role for himself and for the writer in general, alongside the Russian artist.

It is worth noting in passing that several writers later made similar use of ecphrasis as a stepping-stone to pass from visual to verbal prophecy. In his letters of 1820 about his visit to the Dresden art gallery Glinka's younger contemporary Kiukhel'beker dwelt on the inspiration he drew from paintings related to biblical prophecy. ${ }^{30}$ In Selected Passages from Correspondence with Friends (Vybrannye mesta iz perepiski s druz'iami, 1847) Gogol used Alexander Ivanov's monumental work-in-progress, The Appearance of Christ to the

in the Smolensk region (where Glinka was born), and the church as the mausoleum-church (destroyed in World War II) built by M. F. Kazakov in 1784-1802 to serve as a burial place and memorial to the father of Ivan Baryshnikov. The haut-reliefs were the work of the sculptor and architect Boris Poliakov (1748/1750-1826), educated at the Academy. See I. V. Riazantsev and O. S. Evangulova, "Sovremennik Pushkina o tserkvimavzolee v 'sele P ...," in Russkaia usad'ba, ed. and comp. N. V. Nashchokina, vyp. 6 (22) (Moscow, 2000), $107-16$.

${ }^{27} \mathrm{Glinka}$, Pis'ma $\mathrm{k}$ drugu, 42.

${ }^{28}$ Ibid., 43.

29،“'Selo P.' [prodolzhenie]: Zhenshchina, kakikh malo,” in ibid., 53.

${ }^{30}$ See "Pis'mo XIX (otryvok iz puteshestviia)" and "Pis'mo XX," in V. K. Kiukhel'beker, Puteshestvie. Dnevnik. Stat'i, ed. N. V. Koroleva and V. D. Rak (Leningrad, 1979), 20-22, 24. Both letters were first published in 1824. 
People, as an illustration of his own prophetic message. ${ }^{31}$ Like Glinka, both writers adopted the informal genre of the letter to a real or imagined reader to increase the impact of their message. Viacheslav Ivanov developed the same technique in his poem on Michelangelo's statue of David, and in his essay of 1909 on Lev Bakst's apocalyptic painting Terror antiquus. ${ }^{32}$ In all these cases the writer's reference to an original image existing in the "real" world served to ground and validate his verbal prophecy.

In 1816-17, Glinka published a tripartite sequel to Letters of a Russian Officer under the title Letters to a Friend (Pis'ma k drugu). In part two (1816) he related how he would settle down at home to read the Bible, exploring the formation of the human mind and passions in this "chronicle of the world." He portrayed the ancient world of the Jewish patriarchs as a primeval society, when the earth was still young and its innocent inhabitants communed with the angels, a world where Abraham sat for days on end outside his tent on the lookout for guests. The point of evoking this idyll was to ask whether the virtues of ancient man could ever flower again in "our already very old world." To show that these virtues still survived in Russia, Glinka described a few scenes he had witnessed, peppering his account with quotations from the Psalms and Isaiah. ${ }^{33}$ In exhorting his contemporaries to rise to the moral heights of their holy forebears, he was in effect taking on the role of a modern-day prophet.

Although the idealization of biblical Jews was commonplace at that time in Russia, as Weisskopf points out, it often went hand in hand with a negative attitude to contemporary Jews, represented as unworthy of their mission, now taken over by the Russians as the "new Israelites." ${ }^{34}$ To his credit, Glinka was a notable exception to this tendency. His positive attitude was no doubt related to the remarkably good relations which prevailed between the tsar and his patriotic Jewish subjects in 1812-15. As Simon Dubnow pointed out, during this period Russian Orthodox Jews saw Alexander I as the protector of their religious freedom; unlike the Poles, who hailed Napoleon as their savior, they were suspicious of the French emperor's proposed liberal reforms, fearful of the threat posed to their traditional religious way of life by the promise of civic equality. ${ }^{35}$

This optimistic mood is reflected in Glinka's detailed account of his visit to the Great Synagogue of Vilna on August 19, 1815. Together with Count Mikhail Miloradovich and

31"Istoricheskii zhivopisets Ivanov" (1846), in N. V. Gogol', Vybrannye mesta iz perepiski s druz'iami, comp. V. A. Voropaev (Moscow, 1993), 136-46. See also Pamela Davidson, "Aleksandr Ivanov and Nikolai Gogol": The Image and the Word in the Russian Tradition of Art as Prophecy," Slavonic and East European Review 91 (April 2013): 157-209.

32“"Il gigante" was published in Ivanov's first collection of verse, Kormchie zvezdy (1901). "'Drevnii uzhas': Po povodu kartiny L. Baksta 'Terror Antiquus' (Publichnaia lektsiia)" first appeared in Zolotoe runo, 1909, no. 4:51-65, and was republished in Ivanov's influential collection of essays, Po zvezdam: Stat'i i aforizmy (St. Petersburg, 1909), 393-424. On Ivanov's reading of Bakst's painting see Pamela Davidson, Cultural Memory and Survival: The Russian Renaissance of Classical Antiquity in the Twentieth Century (London, 2009), 10-11.

${ }^{33}$ "K pochtennomu izdat[eliu] 'Syna otechestva"” (addressed to N. I. Grech), in Glinka, Pis'ma $k$ drugu, 262-63, 265.

${ }^{34}$ Weisskopf, Veil of Moses, $99-109$.

${ }^{35}$ See S. M. Dubnow, History of the Jews in Russia and Poland from the Earliest Times until the Present Day, trans. I. Friedlaender, vol. 1, From the Beginning until the Death of Alexander I (1825) (Philadelphia, 1916), 355-59. 
Prince Dmitry Zubov, he attended the Jewish community's celebration of the tsar's victory over Napoleon. In a fascinating passage from part one (1816) of his Letters to a Friend, he portrayed the magnificent building, adorned by a picture showing the finger of the Almighty pointing the way to Tsar Alexander, led by an angel; the accompanying inscription of God's promise to Moses, "Behold, I send an Angel before thee, to keep thee in the way" (Exod. 23:20) suggests a parallel between Moses and the tsar as divinely protected leaders of their nations. After noting further quotations from the Psalms in Hebrew and Russian, he commended the hospitality of the hosts, admired the violinist's skill, and enjoyed hearing the cantor and choir sing psalms in praise of God, the tsar, and the Russian troops. In this atmosphere, he felt transported back into the world of ancient Jerusalem. ${ }^{36}$ The 1815 celebration in the Great Synagogue of Vilna provided him with the perfect opportunity to integrate his idyllic view of biblical Jews of the past into the Russian present, and for this reason he accorded it a prominent place in his patriotic book of recollections.

\section{ASSUMING THE AUTHORITY OF THE PSALMIST AND PROPHETS IN EXPERIMENTS IN SACRED VERSE}

Glinka's rapid rise to fame led to his election as chair of the Petersburg Free Society of Lovers of Russian Literature from 1819 to 1825 . Significantly, however, despite his early literary successes, he consistently stressed the primacy of heart over mind, and frequently reminded his friends that he fell into writing by chance and wanted to be admired as a person rather than as a writer. ${ }^{37}$

After developing the format of autobiographical prose letters to uplift and guide the Russian nation in a patriotic context that blended national pride with religious idealism, Glinka went on to extend this approach into other, more elevated genres. The prose parable and biblical-style poem enabled him to deliver his core message, reduced to its essentials and invested with all the authority of these traditions. In 1817, for example, in a poem entitled "Rebuke (From the Prophet Isaiah)" ("Uprek [Iz proroka Isaii]"), he assumed the voice of God, couched in the language of the prophet, to reproach his contemporaries for abandoning God in favor of gold and silver. ${ }^{38}$ In 1825 , just before turning forty, he put together two collections of selected writings, both of which reflected his penchant for moral instruction. The first book, Experiments in Allegories, or Allegorical Descriptions, in Verse and in Prose (Opyty allegorii, ili Inoskazatel'nykh opisanii, v stikhakh $i$ v prose, 1826), passed by the censor in September 1825, comprised twenty-five prose parables and thirty-three poems, preceded by a preface elucidating the moral

\footnotetext{
${ }^{36}$ The entry of August 19 occurs in a section entitled "Dnevnye zapiski russkogo ofitsera," in Glinka, Pis'ma $k$ drugu, 212-13. Conversely, Glinka's later characterization of Bogdan Khmel'nitsky as "this new Moses of the people of Little Russia" is highly ironic in view of the horrific pogroms instigated by Khmel'nitsky. See his introduction to "Zinobii Bogdan Khmel'nitskii, ili Osvobozhdennaia Malorossiia," from Part 3 (1817), in Glinka, Pis'ma k drugu, 333.

${ }^{37}$ See Glinka's letters to V. K. Kiukhel'beker (undated, no later than 1817) and V. V. Izmailov (December 13, 1826), in Glinka, Pis'ma k drugu, 468-69, 473-74.

${ }^{38}$ Sochineniia Fedora Nikolaevicha Glinki, ed. [M. P.] P.[ogodin], 3 vols. (Moscow, 1869-72), vol. 1, Dukhovnye stikhotvoreniia (Moscow, 1869), 158.
} 
purpose of the work. The voice of the didactic preacher blended with that of the lyrical hero recounting his dreams, visions, and responses to nature. The use of allegorical form put the author in the position of a sage, guiding the uninitiated reader toward a deeper understanding; Glinka even provided notes to clarify the hidden meaning of some of his parables.

The second book, Experiments in Sacred Verse (Opyty Sviashchennoi Poezii, 1826), reached out to biblical tradition, adopting the voices of the psalmist and the prophets to frame personal and national experience. It was approved for publication on October 12, 1825, by the priest of Kazan cathedral, Gerasim Pavsky (1787-1863). A Hebraist theologian and key player in the controversial project of the Russian Bible Society to translate Hebrew Scriptures into Russian, Pavsky had already published his own volume of translations of the Psalms in $1822 .{ }^{39}$ Glinka signalled his desire to inscribe his verse within the tradition of sacred writings in three ways: visually, by the cover illustration of a harp floating above the clouds, illuminated by a ray of heavenly light (fig. 1); verbally, by the epigraph to the collection, taken from the opening of Psalm 107 (108) on the heart's readiness to sing the Lord's praises; and typographically, by printing all the epigraphs from the Psalms in Church Slavonic orthography and font. ${ }^{40}$

Out of the collection's fifty "experiments," thirty-three (two thirds of the total) carried epigraphs from the Psalms. Under the influence of Zhukovsky's romantic poetics and Byron's popular Hebrew Melodies (1815), Glinka reworked the classic psalm of Lomonosov and Derzhavin into a new, much more expressive medium. ${ }^{41}$ Pushkin coined the apt term "elegiac psalm" to characterize his unique voice, distinct from Lomonosov, Derzhavin, Zhukovsky, and Batiushkov. ${ }^{42}$ In his approach to the Psalms Glinka departed from the practice of his predecessors, taking considerably more freedom with the originals and underlining the personal, confessional aspect of his adaptations. ${ }^{43}$ In an unpublished preface to the collection, he explained that his efforts should not be treated as "literal versions," nor even as "close imitations" of the holy Psalms; his practice was to take the "general meaning" of a whole psalm or just a few verses from one psalm, and to use this as the basis for the creation of his own work, based on the "inspiration that was guided at that moment by my

\footnotetext{
${ }^{39}$ For Pavsky's approval of Glinka's volume see the verso of the collection's title page. For Pavsky's translations of the psalms see Kniga Khvalenii ili Psaltir' na rossiiskom iazyke (St. Petersburg, 1822). For details of the controversy surrounding this publication and different editions see Batalden, Russian Bible Wars, 69-72, 21418. In 1814, as a graduate student of the Petersburg religious academy, Pavsky had already published Obozrenie knigi psalmov: Opyt arkheologicheskii, filologicheskii i germenevticheskii.

${ }^{40}$ This typographic distinction was dropped from the later publication of this collection in Glinka, Dukhovnye stikhotvoreniia (1869).

${ }^{41}$ V. E. Vatsuro, "Poeziia pushkinskogo kruga," in Istoriia russkoi literatury v chetyrekh tomakh, ed. N. I. Prutskov (Leningrad, 1980-83), 2:337.

${ }^{42}$ Pushkin, Sobranie sochinenii, 6:47-48.

${ }^{43} \mathrm{On}$ the differences between Glinka's approach to the Psalms and Trediakovsky's see V. P. Zverev, "Perelozhenie psalma 143 V. K. Trediakovskim i F. N. Glinkoi," in V. K. Trediakovskii i russkaia literatura, ed. A. S. Kurilov (Moscow, 2005), 229-58. Like Trediakovsky, Lomonosov, and Sumarokov, Glinka translated Psalm 143 (144) but did not include it in Opyty Sviashchennoi Poezii or Dukhovnye stikhotvoreniia. For interesting comments on Glinka's relation to his contemporaries' versions of the psalms see T. G. Mal'chukova, "Parafrazy psalmov v russkoi poezii 1820-kh godov," in Khristianskaia kul'tura. Pushkinskaia epokha, vyp. 10 (St. Petersburg, 1996), 64-84.
} 
soul." ${ }^{\prime 4}$ The significant point here is that he was explicitly shifting the authority of the sacred word into the domain of his own subjective "felt" experience.

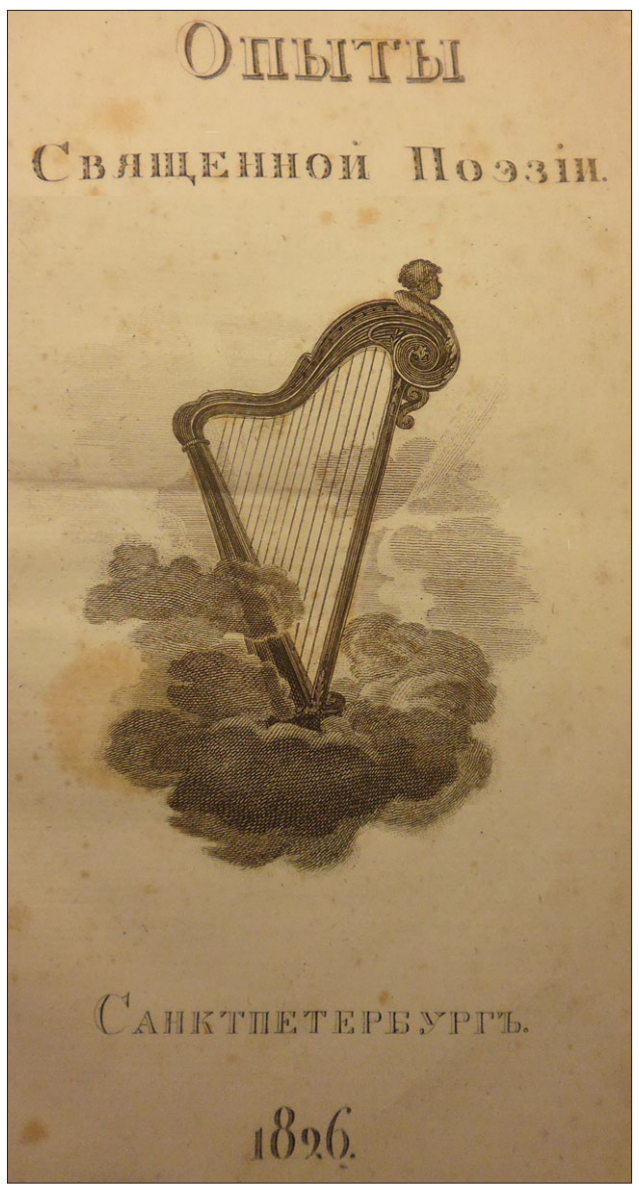

FIG. 1 Cover illustration of Fedor Glinka, Opyty Sviashchennoi Poezii, 1826.

The thirty-three versions Glinka selected for his collection draw on the full gamut of personal emotions and moral teachings found in the psalter. Some render an entire psalm; others develop a single verse, usually cited as an epigraph. Recurrent themes include praise of the righteous contrasted with sinners, appeals to God to punish the wicked, prayers not to be punished too severely, lament in exile, trust in God as sole refuge, the celebration of nature as God's creation, and the anticipation of a Messianic age. As in the original Psalms, personal concerns carry a national and universal dimension; the prophetic tone is maintained

\footnotetext{
${ }^{44}$ Cited from the archival source held among the papers of V. V. Grigor'ev in Tsentral'nyi gosudarstvennyi istoricheskii arkhiv (St. Petersburg), in F. N. Glinka, Izbrannye proizvedeniia, ed. V. G. Bazanov (Leningrad, 1957), 456. Very similar points are made in the "Preduvedomlenie" located in Glinka's archive in Gosudarstvennyi arkhiv Tverskoi oblasti (GATO), f. 103, op. 1, ed. khr. 984, cited in Zverev, Fedor Glinka, 241. A slightly different version of this passage is also cited in F. N. Glinka, Stikhotvoreniia, ed. M. V. Stroganov and L. L. Erokhina (Tver', 2006), 78.
} 
through frequent moral exhortations and expressions of faith in the coming of redemption. Glinka made several pointed changes and additions to emphasize the contemporary Russian background and the poet-prophet's role within this context. This is already clear from the opening poem of the collection, a revised version of a patriotic ode first published as a separate booklet in 1818. ${ }^{45}$ In "A Hymn to God" ("Gimn Bogu"), prefaced by an epigraph from Psalm 50 (51), the psalmist's traditional praise of God as Creator of nature and ruler of the universe rapidly gives way to the poet's own voice. In a series of visions introduced by the prophetic "I behold" (ia zriu), the narrator evokes the arrogant enemy advancing on the ancient capital with fire, and fears that Russia will perish. He then assumes the voice of God resounding from the heavens, promising to protect the freedom of His people. He concludes by reiterating that his heartfelt hymn is addressed to God, like smoke rising from a censer, although he questions his ability as a son of the earth to sing the praises of the Creator. ${ }^{46}$

This example demonstrates how Glinka used the Psalms as a vehicle for his own adoption of the voice of the contemporary poet-prophet, transforming praise of God the Creator into praise of the God of the Russian people, newly victorious over the foreign aggressor. The poet's patriotism is allied with God and the tsar, the universal is related to the historical moment, and the Russian people's role as the new, divinely protected Israel is articulated by the poet as its prophet. This sets the tone for what follows.

To facilitate this transition, Glinka frequently introduces prophetic notes into his versions of the Psalms. In the second poem of the collection, based on Psalm 1, "The Happiness of the Righteous Man" ("Blazhenstvo pravednogo," 1824), he inserts a new dimension of national recognition, absent in the original, but well suited to the role of the poet-prophet:

Он будет памятен отчизне,

Благословит его народ ..." ${ }^{47}$
He will be remembered by the fatherland, The people will bless him ...

As we shall see below, these lines were later used by a contemporary writer to characterize Glinka as a prophetic poet. Likewise, in his version of Psalm 2, "The Vanity of Sophistry" ("Tshcheta suemudriia," 1824), additional lines such as "He armed me with a staff" (On opolchil menia zhezlom) and "I see: it is close, the Godly day" (Ia zriu: on blizok, Bozhii den') transform the psalmist into a prophetic visionary. "A8 "A Voice to the Most High" ("Golos k Vyshnemu") starts off with an epigraph from Psalm 8 and proceeds in the firstperson with reminiscences from this source (lines 1-26). It then unexpectedly changes gear, adding an entirely new section in which the poet-psalmist "cites" God's message to an unnamed Prophet (lines 27-40) before reaffirming his own faith (lines 41-44). The interpolated lines may well have been intended to reflect Glinka's sense of his own calling as the moral teacher of the New Israel:

\footnotetext{
${ }^{45}$ Fedor Glinka, Gimn velichiiu i vsemogushchestvu Bozhiiu (St. Petersburg, 1818).

${ }^{46}$ Opyty Sviashchennoi Poezii Fedora Glinki (St. Petersburg, 1826), 1-6.

${ }^{47}$ Ibid., 8, first published in 1824 under the title "Pravednyi muzh."

${ }^{48}$ Ibid., 10, first published in 1824.
} 
Всемощный! Ты вещаль Пророку: «Земной! Будь голосом Небес! Труби могущему пороку, И светом Божиих словес Очисти смрадные вертепы Змеиных козней и грехов! ...»49
Almighty! You forecast to the Prophet: "Earthly man! Be the voice of the Heavens! Sound the trumpet at mighty vice, And with the light of God's words Purify the stinking dens Of serpent snares and sins! ...”

"Victory" ("Pobeda," 1825) is a close adaptation of Psalm 151, appended to the original Hebrew psalter in the Greek Septuagint translation. It describes the selection of David, the youngest of his brothers, for his prophetic mission, and his defeat of the giant Goliath. The final lines, following the enemy's fall, introduce a strong national flavor:

Он пал, как столп. Цвети, отчизна! He fell like a pillar. Flourish, fatherland! Израиль мой, с твоих сынов Снята позора укоризна:

Не знай ни плена, ни оков! ${ }^{50}$ My Israel, from your sons The reproach of shame has been removed: Know neither captivity nor fetters!

The addition of the title "Victory" and the extra emphasis of these closing lines confirm that this version of the psalm was intended to be read as a retrospective celebration of Russia's overthrow of Napoleon, inaugurating a new age of freedom, and, more generally, as a prophecy of Russia's future defeat of the brute forces of tyranny. By addressing Russia as "my Israel," Glinka clearly presents himself as the nation's prophet.

These examples all confirm that Glinka's approach to the Psalms was very much in the spirit of biblical prophecy: he reproached the nation for its vices, lamented its trials, celebrated its victories, and held out the promise of future redemption. His extensive use of the Psalms rooted him in a tradition already initiated by his predecessors and provided him with a solid moral and religious platform for the next stage - the open adoption of the mantle of prophet. This move was articulated through several poems directly drawn from the Prophets where he assumed a variety of voices, sometimes combined: God addressing the prophet, the prophet speaking to God, or the prophet preaching to the people. Out of the remaining seventeen poems of Experiments in Sacred Verse, nine feature the Prophets: Isaiah (five times), Jeremiah (twice), and Elijah, Ezekiel, and Ezra (once each). In these versions Glinka stuck closer to the authoritative Church Slavonic "original" than in his adaptations of the Psalms, as noted in his draft foreword:

In rendering the prophecies, I tried to keep more closely to the original- that is, of course, to the Slavonic one, sometimes comparing it to translations in foreign languages. I did not, however, follow a strict order, and often combined chapters closely related in meaning. ${ }^{51}$

The prophetic imitations gave the poet a more public, didactic voice and a closer connection to the narod than the introspective meditations of the psalmist. The progression from one type of adaptation to the other is clearly flagged in the structure of the collection.

${ }^{49}$ Ibid., 15.

${ }^{50}$ Ibid., 99, first published in Severnye tsvety, 1825, under the title "Psalom (Podrazhanie)."

${ }^{51}$ From the "Preduvedomlenie" held in Glinka's archive in GATO, cited in Zverev, Fedor Glinka, 239. 
Two prophetic poems are first embedded in the middle of the sequence of poetic psalms. "Searching for God" ("Iskanie Boga") describes the word of God revealing itself to Elijah in a still, quiet voice (1 Kings 19:11-12), while "The Voice of God to His Chosen One" ("Glas Boga izbrannomu Ego") paraphrases God's message to Isaiah, emphasizing His love for His people and readiness to cleanse them of their sins (Isa. 43, 45). ${ }^{52}$ The positioning of these two poems suggests a natural transition from the personal religious experience of the psalmist to the selection of the prophet for a national mission.

The collection culminates in a closing group of seven striking poems, all attributed to the biblical prophets. ${ }^{53}$ These verses chastise the people for their moral shortcomings, warn them of imminent future punishments, and comfort them with the promise of deliverance. In the first of the series, "The Calling of Isaiah" ("Prizvanie Isaii," 1822), the poet assumes the voice of God, charging the prophet to go forth to the people and spread the holy word.

Иди к народу, мой Пророк! Вещай, труби слова Еговы! Срывай с лукавых душ покровы И громко обличай порок! Иди к народу, мой Пророк! ${ }^{54}$
Go forth to the people, my Prophet! Prophesy, proclaim the words of Jehovah! Tear off the veils from cunning souls And loudly denounce vice! Go forth to the people, my Prophet!

The moral nature of his mission is highlighted by the key rhyme of prorok (prophet) with porok (vice) - a recurrent feature of almost all of Glinka's prophetic poems. The emphasis is placed squarely on the narod - the people (not the prophet) must be cleansed of its sins.

Two other new elements appear in this group of poems. Like the previous poem, "The Prophet (From Ezra and Isaiah)" ("Prorok [Iz Ezdry i Isaii]") also closely anticipates Pushkin's poem of the same title. It stands apart, however, because of its use of thirdperson narrative perspective, which objectifies the prophet as an independent figure observed from outside (Glinka's other prophetic poems are all written in the first person, reproducing the voices of God and/or the prophet, following scriptural tradition). The opening stanza describes the moment of the prophet's divine calling:

Тоскуя о судьбе людей, Сидел Пророк в глубокой думе.

И се, из купины немой,

Востек, незримо, глас священный, Как песни тайные небес ...

Сей глас, как древле Моисею,

Вещал: Воздвигнись, Мой Пророк!

Ты будешь Божьими устами!
Worrying over the fate of people, The Prophet sat, deep in thought. And lo, from the silent bush, Rose a holy voice, invisibly, Like the secret songs of the heavens ... This voice, as formerly to Moses, Prophesied: Arise, My Prophet! You will be the mouth of God!

\footnotetext{
${ }^{52}$ See the ninth poem in Glinka, Opyty Sviashchennoi Poezii, 26-27 (the source is given in the poem's epigraph); and the thirteenth poem, ibid., 36-38 (the source is given under the title of the poem).

53“"Prizvanie Isaii," "Iz Proroka Isaii," "Kartina Iudeiskikh nravov (Iz Proroka Ieremii)," "Gnev Gospoda na nechestivykh (Iz Proroka Iezekiilia)," "Prorok (Iz Ezdry i Isaii)," "Glas Proroka (Ieremiia gl. 4, 5 i 6)," and "Venets vremen (Iz Isaii)," in ibid., 143-80.

${ }^{54}$ Ibid., 143.
} 
Иди разоблачай порок

В толпах смущенных суетами:

Звучи в веках живой глагол! !5
Go and unmask vice

Amongst the crowds confused by vanities:

Speak out the eternal living word!

In "The Wrath of the Lord against the Impious (From the Prophet Ezekiel)" ("Gnev Gospoda na nechestivykh [Iz Proroka Iezekiilia]"), Glinka's focus on the heavenly visions seen by Ezekiel before receiving the divine message foreshadows the mystic turn of his later verse. ${ }^{56}$ In his draft foreword he commented on the tough verses that resulted from his efforts to capture the "force, fire, and storm" of the original, and invited the judgment of his "enlightened readers" with humility. ${ }^{57}$

The book closes with the final culminating poem of the prophetic sequence. "The Crown of the Ages (From Isaiah)" ("Venets vremen [Iz Isaii]") conveys a messianic vision of a future age of redemption and peace. Its opening lines echo Trediakovsky's and Derzhavin's renderings of Moses's second song (Deut. 32:1) and, once more, anticipate aspects of Pushkin's "Prophet":

Пророк! внимай Моим словам И воструби их в слух народам: Да слышат небо и земля Мои священные глаголы О таинстве Моих судеб: ${ }^{58}$
Prophet! Hearken to My words

And proclaim them in the ears of the peoples: Let heaven and earth hear

My holy utterances

About the mystery of My destinies:

\section{REINFORCING A PROPHETIC IDENTITY IN EXILE}

In March 1826, two months after the publication of his collection, Glinka was arrested on (unfounded) suspicion of involvement in the Decembrist uprising. He was confined to the Peter and Paul Fortress for thirteen weeks. After his release, he was removed from military service and exiled to Petrozavodsk, where he was kept under police observation until $1830 .{ }^{59}$ As in the case of Kiukhel'beker, the experiences of imprisonment and exile intensified rather than diluted his sense of prophetic mission. He continued to draw extensively on the Psalms and Prophets, applying the lessons learned from his earlier "experiments" to his new life. The main thrust remained religious, rather than political. In his version of Psalm 62 (63), he wrote that isolation only deepens the soul's thirst for closeness to God. ${ }^{60}$ Prison became a metaphor for physical, mortal existence, contrasted with the eternal life of the spirit. In a poetic address "To the Dove (From David)" ("Golubitse [Iz Davida]"), he dwelt on his longing to fly away to the eternal spiritual peace of Mount Zion, combining references to the dove from Psalm 54 (55) ("O that I had wings like a dove! For then

${ }^{55}$ Ibid., 164.

${ }^{56}$ Ibid., 154-63.

57"Preuvedomlenie," cited in Zverev, Fedor Glinka, 245-46.

${ }^{58}$ Glinka, Opyty Sviashchennoi Poezii, 179.

${ }^{59} \mathrm{Glinka}$ was in prison from March 9 to May 31, 1826, before being sentenced to exile (Glinka, Izbrannye proizvedeniia, 238).

${ }^{60}$ First published in Dukhovnye stikhotvoreniia (1869), 249-50, in the section of undated poems. 
I would fly away, and be at rest") with the brief image of the dove's silver wings and golden feathers in Psalm 67 (68). ${ }^{61}$

Later verses composed in exile convey a wide range of emotions from hope to despair. "A Voice" ("Glas," 1827), written on the first anniversary of the Decembrists' exile, took as its springboard a verse from Psalm 50 (51) in which the psalmist prays to hear a message of joy and gladness. In response, the poet hears a voice promising the end of oppression and the revelation of all obscure prophecies. ${ }^{62}$ In some poems, he adopted a tone of lament, bewailing the loneliness of the abandoned prophet, whose voice is no longer heeded..$^{63} \mathrm{In}$ others, such as "The Future (Thoughts from the Prophets)" ("Budushchnost' [Mysli iz Prorokov]"), he returned to Isaiah's vision of a messianic era, when all mankind will recognize God and live in peace. ${ }^{64}$

One poem from this period deserves close attention, as it contains Glinka's most open avowal of his personal aspirations to prophetic status. In an intimate address "To God" ("K Bogu," 1827), the poet confesses that he cannot convey the intensity of his love of God: when his soul is on fire, how can he find adequate words to express his feeling? To describe this difficulty, he draws on the two most famous accounts of the problem of prophetic speech found in Hebrew Scripture. After Moses first learns of his mission from God, he objects that the people will not listen to him or believe him. God gives him two signs, but the prophet remains unconvinced: "O my Lord, I am not eloquent (ne rechistyi), neither heretofore, nor since thou hast spoken unto thy servant (s rabom Tvoim): but I am slow of speech, and of a slow tongue (ia tiazhelo govoriu $i$ kosnoiazychen) (Exod. 4:10). The prophet Isaiah is troubled not so much by the inability to speak as by fear of the impurity of his speech. When granted a vision of the Lord in his glory surrounded by seraphs with six wings (po shesti kryl), he takes fright: "Woe is me! For I am undone; because I am a man of unclean lips, and I dwell in the midst of a people of unclean lips." One of the seraphs flies down and touches his lips (kosnulsia ust moikh) with a burning coal (goriashchii $u g o l$ ') to purify his $\sin$ (Isa. 6:2-7).

In his personal confession and appeal to God, Glinka combines both aspects, directly echoing the language of the two prophets (he even adds a note to clarify the reference to the burning coal in Isaiah). ${ }^{65}$ In the following extract from his poem, the points of overlap are shown in italics:

Мой Бог! я в въграженьи слаб;

Я в пении косноязичен;

Земли отродие и раб,
My Lord! I am weak in expression;

In song, I am of a slow tongue;

A servant of the earth since birth,

${ }^{61}$ Ibid., 261, in the section of undated poems (first published in 1827).

${ }^{62}$ Ibid., 423-24, with the (incorrect) date of 1829 (first published in 1827).

${ }^{63}$ See, for example, "Iliia - Bogu," "Bog - Ilie," "Iz psalma 43-go" (“Zabyl Ty nas, zabyl nas, Bozhe! ..."), "Gimn k Bogu," "Golos proroka," and "Otvet prorokov," in ibid., 241-42, 247, 257, 337-39.

${ }^{64}$ Ibid., 243-44, in the section of undated poems. For other poems from the same collection related to biblical prophecy see "Uprek (Iz proroka Isaii)" (1817), "Iz proroka Malakhii” (1823), "Uprek," "Iz proroka Isaii," "Iz proroka Isaii: k liudiam," "Pesn' v pustyne na meste Gesiongaver" (1829), "Slova Adonai k mechu (Iz Isaii)" (1832), “Iz proroka Isaii”" (1832), and "Unyne (iz pr. Isaii)” (1836), in ibid., 158, 172, 235, 238-39, 240, 421-22, 435-36, 444-45, 458.

${ }^{65}$ Glinka was evidently not familiar with the aggadic account of the infant Moses pressing a burning coal to his lips in the presence of Pharoah (hence his speech defect). 
Еще я к небу не привычен ... Коснись твой шестикрьльий мне Горящим углием язылка! Да совершит мне глас великий, Да даст мне весть о вышине! ${ }^{66}$
I am not yet accustomed to the heavens ... Let your six-winged [seraph] touch

My tongue with a burning coal!

And grant me a great voice,

And give me knowledge of the heights!

Through these precise textual echoes Glinka openly identifies his poetic calling with the mission of the two greatest Hebrew prophets, Moses and Isaiah, and declares his wish to follow their examples by assuming the role of moral teacher and national leader of his people. He has come a long way since his first oblique attempt in 1815 to echo the voice of Moses by describing the haut-relief of the prophet giving the commandments. This later poem offers a much more personal and explicit statement of his aspirations than any of the imitations of the prophets previously published in Experiments in Sacred Verse. Although Glinka published it in 1827 in the conservative monarchist journal Slavianin, he did not include it in his 1869 collection of spiritual verses - times had changed, and perhaps, with hindsight, he found its disarming candor too revealing.

\section{VALIDATING THE POET'S AUTHORITY: CONTEMPORARY READERS' RESPONSES}

There is no doubt, therefore, that Experiments in Sacred Verse was a crucial milestone in the development of the image of Russia as a New Israel and in the resulting empowerment of the poet as a figure of prophetic authority. Its ground-breaking significance for Russian literature was recognized at the time. A sympathetic reviewer (identified as M. A. Dmitriev) praised Glinka for daring to defy contemporary fashion by dedicating his verse to lofty subjects. Placing the book in the broad context of the relationship between Russian poetry and Hebrew sacred verse, he argued that this connection was based on inner inspiration rather than formal imitation (as was the case with the poetry of the ancient Greeks). After considering some precedents (versions of the Psalms composed by Lomonosov, Derzhavin, and Shatrov), he identified three distinctive features in Glinka's approach: his concentration on the religious aspect of the originals, the freedom of his adaptations, and his personal engagement, putting the self at the center of his poetic world. To illustrate these points, he cited the opening "Hymn to God" and the first two prophetic poems of the collection, "Searching for God" and "The Voice of God to His Chosen One," all considered above. ${ }^{67}$

The perceptive points made in Dmitriev's thoughtful review have stood the test of time. Glinka's work was indeed innovative and daring, amounting to a carefully prepared poetic manifesto for his age. It took up the juxtaposition of Psalms and Prophets, common

${ }^{66} \mathrm{Glinka}$, Izbrannye proizvedeniia, 255, first published in Slavianin, no. 26 (1827): 467.

${ }^{67}$ [M. A. Dmitriev], "Opyty Sviashchennoi Poezii Fedora Glinki. S. P. B. 1826 goda," Moskovskii vestnik, pt. 1, no. 4 (1827): 322-30. The identity of the anonymous reviewer is revealed by the editor in a later issue as M. A. Dmitriev (a poet and acquaintance of Glinka's). See Moskovskii vestnik, pt. 2, no. 5 (1827): 110. An earlier review by "O. S." (identified as Osip Senkovsky by Zverev, Fedor Glinka, 267, but as Orest Somov by Weisskopf, Veil of Moses, 100), published in four consecutive issues of the newspaper Severnaia pchela, October 26, 28, and 30 and November 2, 1826, nos. 128-31, also placed considerable emphasis on the adaptations of psalms and prophets (Zverev, Fedor Glinka, 267-71). 
in Church Slavonic psalters and echoed by Trediakovsky in the 1752 edition of his works and in his complete psalter of 1753 , but deployed it to new effect. Glinka did not just use this device as the organizing principle around which to structure his collection. He went considerably further than his predecessors, creating a seamless transition from the inner religious experience of the psalmist to the prophet's understanding of the destiny of his nation, viewed from the perspective of divine providence. As noted above, this shift was facilitated by Russia's new sense of historical mission and relation to Europe following the defeat of Napoleon. However, although earlier poets had often linked poetic versions of the Psalms to odes on national events, this connection was not usually expressed in terms of the author's own "felt" experience - it tended to remain outside the personal sphere. In Glinka's subtle interweaving of personal and national motifs, the individual religious experience captured in the Psalms nurtured and validated the grander national prophecies, signalling a new dimension in the relationship between poet and state. He did not share the drive toward political dissent found in the work of Kiukhel'beker and the younger archaists; from the outset, his prophetic vision of the national destiny was of religious origin and deeply patriotic, paving the way for the Russian idea subsequently elaborated by the Slavophiles.

Although Glinka did not apply the image of the poet as psalmist/prophet that he established so firmly in this collection directly to himself (except for the unusually revealing later poem, "To God"), such an association clearly was invited. Not surprisingly, the invitation was taken up. One of his friends, the Russian Orthodox poet Pavel de Roberti, took up all the key elements of Glinka's composite image of prophecy and reflected them back upon their author. In November 1828, de Roberti wrote to the exiled poet, praising Experiments in Sacred Verse and suggesting a more extensive use of New Testament sources in his verse. He rounded off his letter with a poetic address to his friend, "Earthly man! Be the voice of the Heavens! ..." (“Zemnoi! Bud' golosom nebes! ...”). As presaged by this opening line, the entire poem consists of a collage of seventeen lines taken from four poems of Glinka's collection - “A Voice to the Most High" (lines 1-5), "The Prophet" (lines 6-9), "The Voice of God to His Chosen One" from Isaiah 43, 45 (lines 10-13), and "The Happiness of the Righteous Man" (lines 14-17) —all discussed above. Two of these works are from Glinka's prophetic poems, and two from his versions of the Psalms. Significantly, from the second category de Roberti has chosen to quote the prophetic lines added by Glinka. From "A Voice to the Most High" he has selected the opening of God's message to the Prophet. From "The Happiness of the Righteous Man" he has picked out the new references to the fatherland and people, cleverly changing Glinka's third person to second person. The closing lines of his address- "You will be remembered by the fatherland,/ The people will bless you ..." (Ty budesh' pamiaten otchizne,/ Blagoslovit tebia narod ...)turn Glinka's paraphrase of the psalmist's characterization of the righteous man into an affirmation of the poet's own prophetic status, validated by the very narod whose image he sought to redefine. ${ }^{68}$

\footnotetext{
${ }^{68}$ See Pavel Maksimovich de Roberti's poetic address to Glinka in his letter to Glinka of November 3, 1828, Rossiiskii gosudarstvennyi arkhiv literatury i iskusstva, f. 141, op. 1, ed. khr. 381), cited in Zverev, Fedor Glinka, 275 (emphasis added).
} 


\section{THE PARADOXICAL AFTERLIFE OF GLINKA'S LEGACY}

This article has traced the process by which a significant controlling metaphor generated an even more powerful one, which took root on Russian soil and enjoyed a flourishing afterlife. As we have seen, Glinka's initial adoption of the trope of chosenness led to the association of his own role - and, by extension, of the Russian writer's role - with the commanding voice of biblical prophecy. He transformed this voice for his generation by investing the existing theological and imperial constructions of the Russian nation with a new, personal, and historicized portrayal of the narod as a worthy carrier of this holy mission. Initiated in the interlude between the Napoleonic wars in his autobiographical Letters, this gradual process of transformation culminated in his Experiments in Sacred Verse, effectively merging the author's voice with the authority of the sacred word. The fact that his collection, completed well before the Decembrist uprising, appeared in print immediately after this watershed event, did much to reinforce its political as well as literary impact.

This was not, of course, the end of the process, only its beginning. Glinka went on to experiment with the genre of the religious poema, composing four long poetic narratives of progressively more ambitious prophetic scope. ${ }^{69}$ By the end of his long life he had devoted more effort (spread over the course of seven decades) than any other nineteenth-century writer to the development of the image of Russia as a New Israel and, in this context, of its author as the nation's prophet. His identification of the poet with the voices of the psalmist and prophets linked the work of his predecessors (Trediakovsky, Lomonosov, Derzhavin) through contemporaries (Pushkin, Kiukhel'beker, Tiutchev, and the Slavophiles) to younger writers (Dostoevsky, Vladimir Solov'ev) and their Silver Age successors. Through this chain, the concept of Russians as a chosen people and of the prophetic author as their moral teacher migrated from poetry into prose and entered the realm of Russian thought and aesthetics.

Yet there is a curious paradox about Glinka's role in this chain of transmission. Despite his strong sense of civic duty and interest in the narod, during his lifetime his contribution was dismissed as irrelevant by Nikolai Nekrasov, the poet-prophet of the people. In an anonymous review published in 1866 on the pages of Sovremennik, the journal's editor portrayed Glinka and M. A. Dmitriev as venerable old men sitting by the side of the road, long since unable to walk; everything living and forward-thinking had overtaken these "fragments of the past." obvious model for aspiring religious prophets of the next generation to invoke as a predecessor, this did not happen. Instead, Dostoevsky, Solov'ev, and the Symbolists tended to cite less "obvious" candidates, such as Tiutchev, Polonsky, or even Fet, sometimes

\footnotetext{
${ }^{69}$ Glinka's free poetic imitation of the Book of Job (first seven chapters published in 1827; full text published in Berlin, 1859) was followed by three visionary poems: Kareliia, ili Zatochenie Marfy Ioannovny Romanovoi (1828-30; published in 1830); "Videniie Makariia Velikogo" (1840, revised 1847 and 1848; published in 2013); Tainstvennaia Kaplia: Narodnoe predanie (composed from the late 1830s and throughout the 1840s; published in Berlin, 1861; Moscow, 1871). The last work is an epic tale of redemption, which narrates the life of Christ through a series of loosely linked episodes, blending scriptural sources with apocryphal folk legends.

${ }^{70}$ N. A. Nekrasov, Polnoe sobranie sochinenii i pisem v piatnadtsati tomakh, vol. 11:2 (Leningrad, 1990), 259-60 (first published in Sovremennik, 1866, no. 3, otd. II:119-30).
} 
reaching back to Pushkin and Lermontov, but invariably bypassing Glinka. Accordingly, poets other than the one who had cultivated the image most assiduously came to be regarded as the founding fathers of this tradition, while Glinka's much more substantial contribution was largely overlooked.

Hence the need, addressed in this article, to correct this imbalance by reinstating the missing link of Glinka's crucial role. In 1927 one of the most astute Russian critics, D. S. Mirsky, described Glinka as "almost a major ... poet" of "startlingly great" "originality and independence from contemporary example," comparing his style, "at once realistic and sublime," to that of the great Anglican mystic poets, George Herbert and Henry Vaughan. After praising the "great swing and go in his verse, when he speaks of the last judgment, or when he paraphrases the prophets," he drew attention to his anomalous status: "He was never appreciated at his right value, and during his last years he was a favorite target for the ridicule of the young critics. He has not yet been entirely rediscovered, but such a rediscovery is one of the maturest possibilities of Russian literary judgment." ${ }^{\text {"71 }}$ We would do well to heed this perceptive insight.

Mirsky's strong words underscore the need to reach a balanced assessment of Glinka's significance. In the final analysis, how original was his contribution to the image of the writer as prophet within the context of the idea of Russia as a New Israel? The answer to this question must be a nuanced one. On the one hand, as we have seen, his contribution was not an isolated phenomenon: it grew out of an existing tradition, both European and Russian, and flourished at a time when many other writers were also cultivating biblical prophecy. His association with both generations of the archaists, noted in the introduction, is reflected in numerous parallels between his work and that of writers such as Shishkov, Derzhavin, Shirinsky-Shikhmatov, and Kiukhel'beker.

On the other hand, he clearly stood apart from all literary groups, following his own distinctive path. Unlike the older archaists, he introduced a new personal, elegiac tone into his renditions of biblical texts. The overall goal might be the same, but the method was quite different. Shishkov, for example, compiled a collage of scriptural quotations, transcribed verbatim from the Psalms and the Prophets, and read them out to Alexander I to reveal the similarity between Israel and Russia and the providential course of the Napoleonic wars (together they shed tears of heartfelt exaltation). ${ }^{72}$ By contrast, Glinka completely reworked his biblical sources, transforming them into a vehicle for his own individual

${ }^{71}$ D. S. Mirsky, A History of Russian Literature: From the Earliest Times to the Death of Dostoyevsky (1881) (London, 1927), 136-37.

${ }^{72}$ See the introduction and sections headed "Vshestvie vraga $v$ tsarstvo i gordyi pomysl ego," "Razorenie Ierusalima," "Molitva Tsareva" and "Prorochestvo," from "Kratkie zapiski, vedennye v byvshuiu s Frantsuzami v 1812-m i posleduiushchikh godakh voinu," in Sobranie sochinenii i perevodov Admirala Shishkova, vol. 16 (St. Petersburg, 1834), 68-77. Shishkov recounts that he kept quickly written notes during his travels with Alexander I in 1812-13, and later brought them into order (ibid., 18). He began reading the Bible during his travels, and found so many parallels with the current war that he started copying out passages from the Prophets (Isaiah, Ezekiel, Habbakuk, Jeremiah) and the Psalter without changing a word. After ordering these passages, he found a narrative of "our military actions" (ibid., 68-69). He read his notes out to Alexander I and they both wept together (ibid., 77). According to the verso of the title page, he received the Academy's permission to publish his work on May 12, 1817. In May 1831 he asked for and received permission from Nicholas I to dedicate his memoir to him (ibid., 18-20). 
voice. He was also the first writer to address the moral qualities of the "real" Russian narod as evidence of its suitability for the role of chosen people or "New Israel." $\mathrm{He}$ shared many of the aspirations of the younger archaists, but, because of his older age, had a substantial head start. Coupled with his remarkable longevity (he lived beyond the age of ninety-five), this meant that he could carry on developing themes that he had initiated in the 1810 s and 1820 s through to the $1870 \mathrm{~s}$ - even though this caused him to be derided as an eccentric relic from the past. While noting that Kiukhel'beker was frequently mocked and cautioning that his standing should not be exaggerated, Tynianov emphasized that the eccentric poet's failures were nevertheless crucially important for the literature of the $1820 \mathrm{~s}^{73}$ In line with this judgment, we may conclude that Glinka's original contribution was highly significant for the literary process of his time.

${ }^{73}$ Tynianov, ““Argiviane,' neizdannaia tragediia Kiukhel'bekera” (1924-27), in Poetika, 117. 